\title{
Court of Justice of the European Union (Ninth Chamber), wT v Subdelegación del Gobierno en Guadalajara
}

Case C-448/19, Judgment of 11June 2020, EU:C:2020:467

\author{
Diego Acosta \\ Professor of European and Migration Law, University of Bristol, Bristol, UK \\ d.acosta@bristol.ac.uk
}

\begin{abstract}
This case report provides an account of the issues in the preliminary ruling of the Court of Justice of the European Union (CJEU) in the WT case. The case centres on the elements that need to be considered under Directive 2003/109 before expelling a third-country national, holding a long-term residence permit, who has committed a criminal offence. This case report discusses the interpretation of Article 12 of Directive 2003/109, in particular the concept of threat to public policy, describes the incorrect previous reading by the Spanish Supreme Court of that provision, the possible case for a state liability claim against Spain as a result of that, and the importance of the dialogue between lower-level domestic courts and the Court of Justice on migration matters.
\end{abstract}

\section{Keywords}

long-term residence directive - protection against expulsion - public policy or public security - Directive 2001/40

WT is a third-country national holding a long-term residence permit in Spain. In 2016, when completing some formalities related to his residency before the competent police authorities, it was found that he had been sentenced 
between 2011 and 2014 to three terms of imprisonment of more than one year. Administrative expulsion proceedings were subsequently initiated against WT.

Mr WT claimed that, having resided in Spain for longer than 10 years and having there his family and occupational ties, his previous criminal convictions could not justify expulsion from a Member State where he was fully integrated. Mr WT appealed twice against this expulsion order.

The referring court - the High Court of Justice of Castilla-La Mancha, Spain-highlighted that it was bound by the case law of the Supreme Court, which had previously held that long-term residents must be automatically expelled for intentional criminal offences punishable by custodial sentences of more than one year. In order to reach that conclusion, the Spanish Supreme Court had, in two judgments from 2019, taken as its basis Directive 2001/40 on the mutual recognition of decisions on the expulsion of third country nationals. The referring court was of the opinion that this understanding was incompatible with Article 12 of Directive 2003/109 as interpreted in Ziebell (C-371/08), and López Pastuzano (C-636/16). The national provision at stake was Article 57 of the Spanish Immigration Law.

Having regard to this, the referring Court decided to stay the proceedings and to refer one question to the CJEU for a preliminary ruling: 'Is an interpretation such as that set out in judgments of the Tribunal Supremo (Supreme Court), according to which, through an interpretation of Directive 2001/40, it is possible to come to the conclusion that any third-country national holding a long-term residence permit who has committed an offence punishable by a [custodial] sentence of at least one year must be "automatically" removed, that is to say, without it being necessary to give any consideration to his personal, family, social or employment circumstances referred to in Directive 2003/109, compatible with Article 12 of Directive 2003/109, and with the previous case law interpreting it?

Addressing the question referred to it, the Court clarified that Directive 2001/40 is evidently not applicable in the circumstances of this case. As it is clear from Article 1(1) of Directive 2001/40, its material scope relates to the recognition by one Member State (the enforcing Member State) of an expulsion decision issued by a competent authority of another Member State (the issuing Member State).

By contrast, Article 12 of Directive 2003/109 is applicable. The Court reiterated its interpretation in López Pastuzano where it had already ruled on the 
compatibility of the same national provision as in the present case, namely Article 57 of the Spanish Immigration Law. with Article 12 of Directive 2003/109. As it was clear from that case, the Court continues, Article 12 precludes a Member State from adopting a decision to expel a long-term resident TCN "solely on the basis of criminal convictions against him in the past, without determining whether that third-country national represents a genuine and sufficiently serious threat to the public order or security of that Member State, or taking into account of the various factors listed in paragraph 3 of that article" (paragraph 24).

\section{Decision of the CJEU}

Article 12 of Directive 2003/109 must be interpreted as precluding legislation of a Member State which, as interpreted by national case-law with reference to Directive 2001/40, provides for the expulsion of any third-country national who holds a long-term residence permit who has committed a criminal offence punishable by a custodial sentence of at least one year, without it being necessary to examine whether the third country national represents a genuine and sufficiently serious threat to public order or public security or to take into account the duration of residence in the territory of that Member State, the age of the person concerned, the consequences of expulsion for the person concerned and family members and the links with the country of residence or the absence of links with the country of origin.

\section{$4 \quad$ Commentary}

On the face of it, $W T$ is a straightforward case where the CJEU reiterates the interpretation of Article 12 of Directive 2003/109 in López Pastuzano. The case is however important in that it highlights the centrality of the dialogue between lower-level domestic courts and the Court of Justice through the preliminary ruling procedure, and opens the path for a possible state liability claim against Spain due to the breach of EU law by its Supreme Court.

Spain, which has the fourth largest population of TCNs in the EU, has only recently become an important Member States in terms of the number of references for preliminary rulings on migration law, particularly on the Returns Directive 2008/115 (C-38/14 Zaizoune), family reunification Directive 2003/86 (C-558/14 Khachab) or the long-term residence directive itself (C-636/16 López Pastuzano). What all these cases have in common, other than they have been 
referred in the last five years, is that they all come from lower-level courts in Spain. This judicial dialogue has been a new discovery for some Spanish courts. In this particular case, there were no less than five other references on the same situation involving Directive 2001/40 from Spanish lower-level courts (C-567/19, C-549/19, C-534/19, C-533/19 and C-531/19).

This large number of references can be explained by the absurdity of two Spanish Supreme Court rulings in cases STS 580/2019 and sTs 663/2019. Faced with the possible expulsion of a long-term resident who had committed a criminal offence in each of these cases, the Supreme Court left aside Directive 2003/109, ignored the CJEU's case law on Ziebell and López Pastuzano, and applied instead Directive 2001/40. All this was done without even discussing whether a reference for a preliminary ruling would have been appropriate and needed. This irrationality would be apparent even to the non-lawyer. Article 1 of Directive 2001/40 explains its purpose which is

to make possible the recognition of an expulsion decision issued by a competent authority in one Member State, hereinafter referred to as the "issuing Member State", against a third country national present within the territory of another Member State, hereinafter referred to as the "enforcing Member State".

The fact that there was no distinction here between the issuing and the enforcing Member State, which was in both cases Spain, did not stop the Supreme Court in its ludicrousness. Moreover, any last instance court, particularly a Spanish one, should have been aware of the CJEU's order in Case C-456/14 Orrego Arias following a reference for a preliminary ruling from a Spanish court. In this order, the CJEU acknowledged its lack of jurisdiction, and thus did not produce a ruling. However, the CJEU clarified that Directive 2001/4O did not apply to cases involving Article 57(2) of the Spanish immigration law since there was only one Member State involved, Spain, rather than two, as it was needed in order to apply the Directive.

The Spanish Supreme Court also decided to ignore Ziebell and, even more astonishingly, López Pastuzano, a case that having its origin in Spain also dealt with Article 57 of its Immigration Law. In López Pastuzano, the CJEU did not engage in an extensive analysis of which long term residents could be considered to be an actual and sufficiently serious threat to public policy or public security to begin with. However, its reference to the Ziebell case was central to its decision (para 27). In Ziebell, the Court interpreted Article 12 of the Directive on the basis of a comprehensive summary of its case law on Article 14 of EEC-Turkey Association Council Decision 1/80 (which concerns the 'public 
policy and public security' exception to the rules on residence of Turkish workers and their family members). In brief, the same interpretation of the concept of public policy as in the area of EU nationals applies by analogy; since this is a derogation on a right it needs to be interpreted strictly; measures on grounds of public policy may be taken only following a case-by-case assessment by the competent national authorities showing that the personal conduct of the individual concerned constitutes at present a genuine and sufficiently serious threat to a fundamental interest of society. In addition to that, the principles of proportionality and the respect for the fundamental rights of the individual, in particular, the right to privacy and family life, must be respected, and 'such measures cannot be ordered automatically on general preventive grounds following a criminal conviction or as a means of deterring other foreign nationals from committing offences' (Ziebell, para 83). Finally, the existence of 'previous criminal convictions is, in itself, irrelevant for justifying an expulsion' and 'the same must hold all the more true for a justification relating to the duration of any prison terms to which the individual concerned was sentenced.' In line with this, national courts and national authorities must take into consideration 'factual matters which occurred after the final decision of the competent authorities which may point to the cessation or the substantial diminution of the present threat which the conduct of the person concerned constitutes to the requirements of the fundamental interest in question' (Ziebell, para 84).

This protection is very similar to the one that EU nationals enjoy under Article 27 of Directive 2004/38, if not the same. As the CJEU established in the H.T. case (C-373/13), relating to refugee law, whilst 'EU Member States retain the freedom to determine the requirements of public policy and public security in accordance with their national needs, which can vary from one Member State to another and from one era to another ... the extent of the protection a society intends to afford to its fundamental interests cannot vary depending on the legal status of the person that undermines those interests' (para 77). Similarly, in cases involving the interpretation of the concept of public policy under Article 7(4) of the Returns Directive 2008/115, the Court has been clear in establishing that the concept presupposes 'the existence, in addition to the disturbance of the social order which any infringement of the law involves, of a genuine, present and sufficiently serious threat affecting one of the fundamental interests of society' (see Case Zh. and O., C-554/13, para. 6o and more recently Case $W M, \mathrm{C}-18 / 19$, para 43). This has important implications for all domestic courts deciding in cases where a long-term resident might have committed a criminal offence and when the particular application of the personalised proportionality assessment will be central in deciding the outcome of the residence of the individual or his or her expulsion. 
In $W T$, the CJEU simply reiterates its findings in López Pastuzano, and indirectly in Ziebell, which have just been explained (paras 20-21). It then confirms what was evident, namely that Directive 2001/40 does not 'govern the conditions for the adoption, by a Member State, of such a decision in respect of a third-country national who is a long-term resident and who is on its own territory' (para 24). Interestingly enough, the Spanish Supreme Court had already reached this understandable conclusion, more than a year after its two erroneous rulings in early 2019, when in March 2020 it established that it was 'obvious' that Directive 2001/40 was not applicable in these cases where the 'enforcing and the issuing Member State coincided' (STS 753/2020, 4 March 2020).

In $W T$, the CJEU is subtle in the way it reprimanded the Spanish Supreme Court. The CJEU establishes that whilst it is not for the Court to determine whether the referring court's reading of the judgments of the Tribunal Supremo (Supreme Court), which it cites in this request, is correct, nor whether those judgments infringe EU law (...) [i]t is, however, for the Court to indicate to the referring court whether Article 12 of Directive 2003/109 precludes national case-law having the scope which that court ascribes to the abovementioned judgments of the Tribunal Supremo (Supreme Court)' (para 18).

The ruling opens the door for a possible state liability claim against Spain. Following Köbler, a claim for state liability might be presented when the damage is the result of a national court adjudicating at last instance. The infringement of EU law 'will be sufficiently serious where the decision concerned was made in manifest breach of the case-law of the Court in the matter' (Case C-224/o1 Köbler, para 56). The Spanish Supreme Court engaged in at least three breaches of EU law. First, an interpretation on its own of Directive 2001/40 could never lead to a conclusion that it applied in the case at hand. Second, it ignored the jurisprudence of the CJEU in Ziebell and López Pastuzano. Third, a court of last instance can never decide on a normative conflict between two Directives without requesting a preliminary ruling (see for example Commission $v$ France C-416/17, paragraphs 105-113). The number of TCNs, holding a long-term residence permit, who have been illegally expelled from Spain following the application of Directive 2001/40 is difficult to assess. Spanish lawyers have in any case an opportunity to bring a claim for state liability in such cases.

Finally, the importance of the dialogue between lower-level courts and the CJEU becomes apparent in this case. This is particularly important in the case of Spain where the Supreme Court seems to be ignorant of EU migration law in this case and others. Spanish domestic lawyers need to continue their efforts to convince judges of the importance of such dialogue so that it becomes the norm, rather than the exception. 